\title{
Camtasia as English Learning Video in EFL Classroom: Response of its Implementation
}

\author{
Subakti, MP' ${ }^{1}$, Agustini DAE ${ }^{2}$ \\ ${ }^{12}$ English Language Education, Universitas Pendidikan Ganesha, Singaraja, Bali, Indonesia \\ *Corresponding author: pujasubakti23@gmail.com,
}

\begin{abstract}
Since Educational industry 4.0 reflects the current style of teaching and learning process, the integration of technology-based learning media has been highly demanded. Thus, various types of learning media including video have been widely implemented. This policy was then the basis of this present study to describe teachers' and students' response towards the implementation of animated learning video developed by using Camtasia in elementary schools. This study made use of a descriptive qualitative study. The data were collected through observation, questionnaire, and interviews. The result of this study clearly indicates that by offering animated learning video, the learning activity becomes more attractive even more affects the students' understanding, especially in building vocabulary mastery. As the result, the animated learning video developed has been acknowledged as an effective learning media. As the advantage, this study can enrich students' learning experience in learning English.
\end{abstract}

Keywords: Camtasia, English learning video, response, young learners

\section{Introduction}

The development of technology in Indonesia can be a very good potential in the effort to improve the quality of Human Resources (HR). The implementation of technological developments can create a more effective and efficient educational process. The development of Industry Revolution 4.0 also takes a role in the development of the educational field. The educational system needs to apply the term of Industrial 4.0 in order to achieve the goals in this globalization era. According to Anggraeni (2018) states that Industrial 4.0 gives impact to other fields including educational in which by the use of technology. The use of technology then is a crucial for involving better learning experience. According to Pappas, Mikalef, \& Giannakos (2016), video-based learning is defined as a learning process which acquires knowledge, competence, and skills with the systematic assistance of video resources. Whereas, developing learning video can provide a solution for better learning experience in educational field.

Education 4.0 has a reflection toward innovative learning and the utilizing of technology in learning (Puncreobutr, 2016). He views that Education 4.0 fully concerns on the learning management which helps the students develop their skills by implementing the new technology as well as following the society changes. It means teachers as the facilitator of 
learning have to change their teaching style and get into proper one as the act of adaptation in order to respond to technological development. As this study related to the developing videobased learning, the product developed was adapted technology for students at elementary level. Moreover, elementary students learn vocabulary best by seeing the object directly through video (Gilakjani \& Branch, 2012). In this case, the development of learning media especially video-based learning is appropriate for the students at elementary level because it provides visual object.

Video made by using Camtasia allows teachers to develop an effective learning video. Video created by using Camtasia is categorized as learning media in which valid, easy to use and effective (Retno, 2014). Furthermore, Setyorini (2016) proposed that learning video is an alternative media to be used for teaching in order to engage students in the learning activity. Learning video is suitable media to be implemented in the elementary level of students because it is capable to encourage them to study and understand every single concept vividly because learning video has the capacity to motivate students (Beshnizen and Van Puthen in Akerele, 2012). Moreover, Camtasia promotes videos that students can watch as their homework and apply the concept that they have achieved through learning video. By developing Camtasia as media to teach English through E-learning, the teacher is capable to make learning video in which consist of animated content, engage the visual effect, and quizzing function (Pramudito 2013:4). Those elements are essential to help students during learning process.

Recalling the rapid development of technology, especially in the field of digital technology then there is always a problem of lack in technology-based media used in elementary schools. At last, it may affect the learning goals which the learning objectives will be slower to be achieved. All in all, language learning requires time and effort. Most of the time students at the elementary level are easy to lose their interest and have difficulty towards learning English due to negative feeling in which students easily get bored because of conventional teaching style. However, it is not impossible to make students more willing to learn. By making lessons more appealing through using an innovative learning video as a media is one of the best solutions that teachers can implement in their classroom. Fatunmbi in Akerele (2012) supports that developing learning video can make learning more realistic and it will make the students easier to develop the material also keep students in their concentration during the learning process. 
The video produced is helpful in visualizing the process and allowing the repetition toward the materials in which appropriate to adopt for elementary level students. Besides, many researchers have been studied about developing Camtasia as a mediator for helping students. In this study, Camtasia as the media to produce learning video was allocated to help the teacher in providing an innovative English learning video. For this reason, Camtasia video-based learning is implemented to teach English where students can access in the classroom with the teacher's provision and outside the classroom by using their gadgets. Moreover, the development of technology in Education 4.0 is reflected in the learning process through integrating technology. This study is conducted to describe the teacher's and students' response to the implementation of the animated video developed by using Camtasia as the learning media. This study was conducted in EFL elementary classroom.

\section{Materials and Methods}

This study was a descriptive qualitative study. The population of this study was fifthgrade students in SD Negeri 3 Banjar Jawa in the academic year 2018/2019. The total participant when the product implemented were 31. It divided into an English teacher and 30 students of the $5 \mathrm{~A}$ class. This research was conducted on $10^{\text {th }}$ June 2019 . The data collected through observation, interview, and questionnaire. The instrument used were observation sheet, interview guide, and scoring rubric.

In order to study the response of teacher and students on the effectiveness of learning video developed by using Camtasia, the data were analysed qualitatively by referring the content analysis. In which observation, interview, and questionnaire were done after the learning video has introduced in order to find out the teacher's and students' response toward the learning video being developed.

\section{Results and Discussion}

\section{The Result of the Questionnaire}

The questionnaire was used in order to get information toward response of learning video. It has ten items that represented a good learning video. In addition, the rubric stated some points which the uniformity material with the syllabus, the uniformity material with students' characteristics, and clarity of language use. The result of the questionnaire represents how the teacher perceives the learning video developed. Furthermore, the detail explanation about each item in the rubric is described in the table as follows. 
Table 1. Teachers' response of the learning video implementation

\begin{tabular}{clc}
\hline No. & Statement & Score \\
\hline 1. & The text is placed in a visible place and easy to see. & 3 \\
2. & The selecting shape of the text box should be interesting, simple, and not & $\sqrt{ }$ \\
disturb the main material. & $\sqrt{ }$ \\
3. The selecting color is clear and matches with the color of the background & $\sqrt{ }$ \\
4. The choice of the colors should be excessive and attract students' attention & $\sqrt{ }$ \\
5. The integration of color choices enhances the realism of the material & $\sqrt{ }$ \\
6resented. & The transition of the presentation has good timing. & $\sqrt{ }$ \\
7. The properness of selecting background picture which can exaggerate and & $\sqrt{ }$ \\
8. divert students' attention. & The use of picture is not exaggerated and reflects the real object. & $\sqrt{ }$ \\
9. The backsound is various and attract students' attention to learn. & $\sqrt{ }$ \\
10. The backsound does not distract the students' concentrate. & $\sqrt{ }$ \\
\hline
\end{tabular}

As the questionnaire filled by an English teacher in SD Negeri 3 Banjar Jawa. It can be concluded that the English teacher totally agreed that learning video developed by using Camtasia was suitable for the fifth-grade students. Moreover, The English teacher accordingly stated that the learning video developed by using Camtasia was effective to be implemented for the fifth-grade students, especially in SD Negeri 3 Banjar Jawa. It is because of each aspect consisted in the video was appropriate for fifth-grade students.

The good response for the learning video was also shown by the students, as a result of observation during the implementation of the video in the classroom. The vivid activities that showing the students' response are shown in the table below.

Table 2. Students' response of the learning video implementation

\begin{tabular}{clcc}
\hline No & Activities & Yes & No \\
\hline 1. & The students are able to see the video clearly. & 30 & - \\
2. & The students are able to hear the audio of the video clearly. & 30 & - \\
3. & The students concentrate when learning. & 30 & - \\
4. & The students are enthusiastic in the learning process. & 30 & - \\
5. & The students are enjoying doing the task. & 30 & - \\
6. & The students ask if they find any problem. & 30 & - \\
7. & The students always do the task given by the teacher. & 30 & - \\
8. & The students are active in responding to the instructions. & 30 & - \\
9. & The students are easy to understand the material & 30 & - \\
\hline
\end{tabular}

Based on the observation in the classroom, the students were showing enthusiastic during the implementation of learning video. The students can see the video clearly even for those who sit at the back side. The audio provided in the video was clear to be heard for a whole students in the classroom. The students were absolutely concentrated during the learning process using video. The enthusiasm of the students was indicated as long as the video played in the classroom. They were also enjoy doing the task and give response when the teacher asked 
questions. The students asked the teacher when they had something to ask as well as do the task given by teacher's instruction. At the end, they were understand the material when the teacher emphasized some points which consisted in the video. Moreover, it means that they clearly perceived that the learning video developed by using Camtasia was interesting and motivated them in learning English.

\section{Discussion}

The implementation of learning video produced by using Camtasia significantly affects to the teaching and learning process in the classroom. The following teacher's and students' response toward its development are including Camtasia learning video occurs excitement, understanding, enjoyable, and effective media for teaching-learning process.

The learning video developed by using Camtasia was considering the aspect of appropriateness for the range of young learners in order to get their excitement. The result of observation showed that the students were excited when the learning process used video as learning media. Based on the interview, it could be underlined that the students could get their excitement during learning process by the development of learning video because it contained picture, sound, and information with interesting form. This is in accordance with Akerele (2012) that learning video is suitable media to be implemented in the elementary level of students because it is capable for encourage them to study and learning video has the capacity to interest the students for learning. As the result of students' responses to the learning video, it could be proposed that learning media developed by using Camtasia could bring an exciting atmosphere during the teaching-learning process. This is supported by Bauk \& Radlinger (2013), developing Camtasia can make the content more engaging for teaching and it is suitable software for producing an interesting video. It means that learning video developed by using Camtasia can make the teaching process be more interesting and engaging for the students as well.

In addition, the video was indicated as good learning video based on questionnaire of teacher's response. It is supported by Muhanna (2018) that the learning video produced by using Camtasia is capable to gain students' excitement and the learning process more become beneficial. This study provides evidence that using videos and new means such as Camtasia can make teaching process becomes more effective (Retno, 2014). Moreover, the product developed was indicated as good learning video based on the teachers' response toward product development. It is supported by research from Ciputra (2014), the Camtasia learning video is more effective than conventional learning. Camtasia based multimedia provides a significant 
positive effect on learning outcomes because Camtasia learning video is more innovative and interactive rather than other learning media (Rahayu 2013:26).

Camtasia learning video can generate students' understanding through good quality pictures and sounds. One study in line with this statement was conducted by Adisor (2008) who states that students at the elementary level tend to enjoy the learning flow if their teacher uses learning media which maximizes the audio and visualization to support the learning activity in order to get students' understanding in learning. It is supported by the result of students' interview. They claimed that learning English could be understood by providing video because it contained a good picture, sound, and explanation. As the students' needs, they preferred their teacher to use learning media in the form of video-based learning. They also claimed that technology-based learning could motivate them in learning English. According to Wang (2015), video can give more valuable benefits for students' learning experience, enrich students experience about language in use, improve their cross-cultural understanding, develop their creativity, and increase their motivation in learning.

The video-based learning is used as learning media that can enhance students' enthusiasm. As the result of the interview, the students claimed that they like the way in learning by using video as media and they got enthusiastic toward the learning activity in such a way. The observation also showed that the students enthusiastically followed the learning activity in the classroom. Setyorini (2016) points out that learning video is an alternative media to be used for teaching in order to get students' enthusiasm in the learning activity. It means that learning video developed by using Camtasia can make the students enthusiastic during learning activity. The students' enthusiastic appeared because the video introduced was interesting for the learning process. Thus, by seeing the result of students' interview, then they replied to the question and stated that the video was very interesting. It can give a better learning experience if the students interest in the learning media. It is supported by Heilesen (2009), video-based learning can support better learning and improve students' skill. At last, the learning video implemented can provide for a better learning experience and can generate students' interest to study.

Another advantage of using Camtasia learning video felt by both teacher and students is the effectiveness of the media into the teaching-learning process. Through learning video using Camtasia, it generates the enjoyable of the students toward the learning activity which is accumulated as an effective learning process. As the result recorded in in students' interview, they expressed their feeling by conveying words of really like with high intonation. It means that the video based learning can be an effective media for learning because the students can 
enjoy the learning activity. This is supported by Retno (2014) that a video created by using Camtasia is categorized as learning media in which valid, easy to use and effective. Moreover, the learning video developed by using Camtasia was indicated as appropriate learning media for teaching English. The supporting reason had appeared from students' response and the scoring rubric filled by experts design and media. When the learning video was introduced in the classroom, the students were unconsciously paid more attention toward the video. Saigh (2015) says that Camtasia as learning media leads the students into positive attitudes. The students showed their positive attitude through their interest when the learning video was implemented in the classroom. Arfiyanti, Nuryanti, Widodo, \& Arigiyati (2018) state that Camtasia learning video is an intermediary in the form of learning resources that contain visual material and even audio that can be used for teaching learners and support the learning activities.

\section{Conclusion}

In conclusion, as the result that gained from the students then it could be underlined that fifth grade students in SD Negeri 3 Banjar Jawa were interested in learning English because of learning video provided by the teacher. Their motivation in learning English was increased if the teacher provides technology based learning media. Furthermore, the excitement of the fifth-grade students in learning English using technology including smartphone and laptop also affect the learning quality. In addition, by seeing the result of the teacher's response, then the learning video developed by using Camtasia is suitable to be implemented for the fifth-grade students of elementary level.

In addition, by considering the students' response toward the video implemented in the classroom, it can be concluded that the fifth grade students in SD Negeri 3 Banjar Jawa were interested with the video-based learning in which used as learning activity and they tended to understand the material given when the teacher provided video as the media for learning English.

Since this study was conducted in the fifth grade, then evaluation involving wider range of classroom or school is needed to know how students' engagement toward the development of learning video support better learning experience. 


\section{Acknowledgement}

The writer would like to thank to the principal of SD Negeri 3 Banjar Jawa for giving permission to conduct this study, the English teacher and fifth grade students who give willingness for this study.

\section{Reference}

Akerele, J.A., Adeola, F.A (2012). "Effect of video on the teaching of library studies among undergraduates in adeyemi college of education ondo". Library Philosophy and Practice 2012. Retrieved from http://unllib.unl.edu/LPP/

Arfiyanti, R., Nuryanti, M., Widodo, S. A., \& Arigiyati, T. A. (2018). Camtasia studio learning video for mathematical literature levels students. https://doi.org/10.4108/eai.21-92018.2281180

Anggraeni, C. W. (2018). Promoting education 4. 0 in English for survival class : What are the Challenges ?, 2(1), 12-24. https://doi.org/10.31002/metathesis.v1i2.676

Bauk, S., \& Radlinger, R. (2013). Teaching ECDIS by camtasia studio : making the content more engaging, 7(3). https://doi.org/10.12716/1001.07.03.08

Ciputra, A. (2014). Development of media camtasia studio on learning outcomes computer aided design automotive engineering student at purworejo muhammadiyah university.

Gilakjani, A. P., \& Branch, L. (2012). Visual, auditory, kinaesthetic learning styles and their impacts on english language teaching, 2(1), 104-113.

Heilesen, Simon B. (2009). "Om erfaringer med podcasts i universiteternes undervisning" Laring og medier 2: http://ojs.statsbiblioteket.dk/index.php/lom/article/view/3909

Miller, C. J. (2014). The use of novel camtasia videos to improve performance of at-risk students in undergraduate physiology courses. World Journal of Education, 4(1), 22-n/a. https://doi.org/10.5430/wje.v4n1p22

Muhanna, W. (2018). Using camtasia videos in assigned projects for middle east university students and their attitudes towards it, 8(11), 75-82. https://doi.org/10.30845/ijhss. v8n11p

Nuari, F., Ardi, H., \& M.Hum. (2014). Using camtasia studio 8 to produce learning video to teach English through e-learning. Jelt, 3(September), 1-9. https://doi.org/http:// dx.doi.org/10.1016/0378-4266(81)90050-9

Pappas, I. O., Mikalef, P., \& Giannakos, M. N. (2016, 2016). Video-based learning adoption: a typology of learners. paper presented at the proceedings of the workshop on smart environments and analytics in video-based learning (SE@VBL), LAK2016.

Pramudito, A. (2013). "Pengembangan Media Pembelajaran Video Tutorial Pada Mata Pelajaran Kompetensi Kejuruan Standar Kompetensi Melakukan Pekerjaan dengan Mesin Bubut di SMK Muhammadiyah 1 Playen". Jurnal Pendidikan Teknik Mesin. Hal. 4. Retrieved from http://eprints.uny.ac.id/10393/1/JurnalPenelitian.pdf

Puncreobutr, V. (2018). Education 4.0: New challenge of learning. St. Theresa Journal of Humanities and Social Science, 2(2), 92-97. Retrieved from http://www.stic.ac.th/ojs/

Rahayu, F., S. (2013). "Efektifitas Model Pembelajaran Contextual Teaching and Learning 
(CTL) Berbantuan Power Point, Macromedia Flash, dan Video Pembelajaran Terhadap Hasil Belajar Matematika Siswa Pada Materi Kubus dan Balok Kelas VIII Semester 2 SMP Negeri Karang Tengah Demak Tahun Pelajaran 2012/2013". Unpublished Thesis Semarang. Retrieved from http://library.ikippgrismg.ac.id/\%20docfiles/

Retno, Eli Widoyo., Mardiyana. dan Tri Atmojo Kusmayadi. (2014). Pengembangan model pembelajaran group investigation (gi) berbantu video camtasia pada materi peluang untuk siswa sma/ma negeri kabupaten cilacap tahun pelajaran 2013/2014. Jurnal Elektronik Pembelajaran Matematika. Vol.2, No.5.

Saigh, W. (2015). The attitudes of master educational technology students at king abdul-aziz university towards using camtasia videos in assigned projects. Global Research Journal of Education , 415-422.

Setyorini, Evi Sulis., Isna Tiyaswati., Lisa Faradilla., Rinta Dian Pratiwi. (2016). Pembuatan video pembelajaran menggunakan camtasia studio 7 sebagai media pembelajaran fisika pada materi hukum newton. Seminar Nasional Pendidikan dan Saintek 2016. ISSN: 2557$533 X$.

Wang, Zhaogang. (2015). An analysis on the use of video materials in college English teaching in china. International Journal of English Language Teaching Vol. 2, No. 1;2015. ISSN 2329-7913 E-ISSN 2329-7921. Retrieved from http://puslit.petra.ac.id/ejournal/ index.php/ing/article/view/15498 